Arab World English Journal (AWEJ) $2^{\text {nd }}$ Special Issue on Covid 19 Challenges January 2022 DOI: https://dx.doi.org/10.24093/awej/covid2.28

Pp.426-436

\title{
Taiwanese engineering students' self-efficacy and academic performance
}

\author{
Nga Thi Tuyet Phan
}

Faculty of Foreign Languages

Industrial University of Ho Chi Minh City

Ho Chi Minh city, Vietnam

Corresponding Author: ngaphan2004@gmail.com

\section{Cheng-Hu Chen}

Department of Mechanical and Electro-Mechanical Engineering National I-Lan University, Taiwan

\section{Abstract:}

Despite the popularity and the importance of MOOCs in global education in recent years, they have not become the focus of self-efficacy studies. In addition, most available MOOC research resides in Western economies, not in Asian countries. No studies up to this point have explored the change in engineering student self-efficacy before and after they finish a MOOC or the relationship between engineering students' self-efficacy and academic performance in a MOOC learning environment. This present study examined if there were any changes in the self-efficacy levels of a group of students before and after they attended a blended MOOC on English Technical Writing skills. It explored the relationship between self-efficacy and academic performance and looked for possible differences in self-efficacy and academic performance with respect to different demographic variables. A Paired-samples t-test helped to measure differences in self-efficacy scores at the beginning and end of the course. Pearson correlation was conducted to examine if self-efficacy predicted students' course grades at the end of the course. Descriptive analysis, t-test, and ANOVA were used to measure the differences between the mean scores of self-efficacy and academic performance regarding different demographic variables. Results showed that students became more self-efficacious after they attended the blended MOOC. Selfefficacy significantly predicted academic performance. Students who reported higher selfefficacy levels gained better scores. Participants differed significantly in their self-efficacy and academic performance in relation to age group, English proficiency level, and educational level. Suggestions for future research are made based on the results of the study.

Keywords: Asian, MOOC, quantitative, self-efficacy

Cite as: Phan, N. T. T., \& Chen, C. (2022). Taiwanese engineering students' self-efficacy and academic performance. Arab World English Journal (AWEJ) $2^{\text {nd }}$ Special Issue on Covid 19 Challenges (2) 426-436. DOI: https://dx.doi.org/10.24093/awej/covid2.28 
Arab World English Journal (AWEJ) 2nd Special Issue on Covid 19 Challenges January 2022

Taiwanese engineering students' self-efficacy and academic performance

Phan \& Chen

\section{Introduction}

Since online learning brings learners and teachers many remarkable benefits, including flexibility and life-long learning, many colleges and universities around the world have delivered their courses on an LMS or CMS as an alternative to traditional teaching and learning environment (Singh \& Thurman, 2019). MOOCs (Massive Open Online Courses) have recently become the next big thing in higher education's technological evolution for several reasons. Learners can access MOOCs easily and conveniently via the Internet regardless of location, gender, age, educational background, and culture (Anderson, 2013). MOOCs on primary platforms such as Coursera, Udacity, and Edx allow worldwide learners to actively plan a learning schedule that is appropriate for them. In addition, they can learn from the best instructors and access the most updated knowledge with free or close to free tuition fees (Greene, Oswald, \& Pomerantz, 2015). As a result, the number of students participating in MOOCs has been increasing recently (Pouezevara \& Horn, 2016; Singh \& Thurman, 2019). However, there are still many challenges related to the process of teaching and learning through MOOCs. Some of the critical problems include the high drop-out rate of MOOC participants when compared to the traditional online learning environment (Daniel, 2012; Sandeen, 2013), the higher number of MOOC participants in developed countries than in developing ones (Hamber, Jaffrey, \& Murphy, 2015; Ma \& Lee, 2018), a majority of students from English and Spanish speaking countries than from nonEnglish speaking world (Hamber et al., 2015), and a higher completion rate from developing economies than from developed countries (Ayoub, Amin, \& Wani, 2020). Therefore, it is important to understand what can encourage more students from different areas of the world to attend MOOCs and what can help them retain their learning.

Pajares and Valiante (2002) suggested the relationship between learners' self-efficacy beliefs and their learning behaviors. Students tend to choose tasks that they already think they can do. High self-efficacy levels can bring positive impacts on students' performance. Research has indicated the relationship among students' self-efficacy, engagement, and academic achievement in different learning areas (Ghazali, Nordin, Abdullah, \& Ayub, 2020). Selfefficacy has been investigated much in literature (Klassen \& Usher, 2010), however, only a small number of studies exploring it in a MOOC environment (Rabin, Henderikx, Kalman, \& Kalz, 2020). Therefore, the purpose of this study is threefold: a) to examine if there were any changes in the self-efficacy levels of a group of students before and after they attended a MOOC, b) to explore if self-efficacy predicted their academic performance, and c) to figure out if there was any significant difference in self-efficacy and academic performance with respect to different demographic variables. It is expected that the results of this study will suggest ideas for the improvement of students' self-efficacy and academic performance in a MOOC learning environment, which will hopefully improve the drop-out and enrolment rates of MOOC learners. The study answered the following research questions:

RQ1: Is there any significant difference in the self-efficacy levels of the students before and after attending a blended MOOC?

RQ2: What is the relationship between the students' self-efficacy beliefs and their academic performance?

RQ3: Is there any significant difference in the students' self-efficacy and their academic performance as related to English proficiency level, education level, age, and the number of prior MOOCs? 
Arab World English Journal (AWEJ) 2nd Special Issue on Covid 19 Challenges January 2022

Taiwanese engineering students' self-efficacy and academic performance

Phan \& Chen

\section{Literature Review}

\section{Students' Self-Efficacy Beliefs}

Self-efficacy refers to "people's judgments of their capabilities to organize and execute courses of action required to attain designated types of performances" (Bandura, 1986, p. 391). In the educational sector, self-efficacy is considered an essential contributing factor affecting learners' perceptions, choices, and behaviors (Pajares \& Valiante, 2002, p. 116). Learners build up their self-efficacy by selecting and internalizing information from four sources: mastery experiences (past performances), vicarious experiences (watching others' performances), social persuasion (verbal comments from important people), and psycho-physiological states (feelings, emotions, sickness). Of the four sources, mastery experiences are the most effective way of building selfefficacy. If learners have successful experiences relating to current tasks, they will likely be more confident and display a positive manner to perform the tasks (Hodges, 2016).

Self-efficacy is context-specific (Zimmerman \& Kulikowich, 2016). A student who is selfefficacious in onsite courses will not likely be confident in online courses or MOOCs as each learning environment requires different abilities and resources from the students. Students who attend online courses are required to have computer and Internet skills (Taipjutorus, Hansen, \& Brown, 2012) as well as self-regulated and self-directed learning skills to study effectively without the physical presence of peers or instructors (Chang, Tseng, \& Kang, 2015). They may feel separated and isolated owing to the lack of face-to-face social interaction opportunities (Branson, 2017). MOOC students need the technical skills for online learning to succeed because MOOCs are online courses (Willis, 2013). In addition, MOOC learners are exposed to a more serious lack of social interaction and support (Lee, Watson, \& Watson, 2020) because of the massive nature of MOOCs (Pouezevara \& Horn, 2016). Also, MOOC students who are nonnative speakers of English are expected to obtain good English language skills to attend MOOCs delivered in English in primary platforms (Chung, 2015; Pouezevara \& Horn, 2016).

\section{Student self-efficacy in a MOOC environment}

Despite the popularity and the importance of MOOCs in global education in recent years, they have not become the focus of self-efficacy studies (Kao, Tsai, \& Shih, 2014). Most of the available research has investigated self-efficacy in traditional onsite or online learning environments (Rabin et al., 2020). A search for relevant English language publications in peerreviewed journals between 2010 and 2021 yielded a limited number of self-efficacy studies in a MOOC environment. Among available studies, researchers have often examined the influence of student self-efficacy on MOOC behaviors and the relationship between MOOC self-efficacy and other constructs. A few researchers have explored the antecedents of self-efficacy in a MOOC environment and changes in self-efficacy levels before and after learning a MOOC. The results of important studies will be reported as follows.

Most of the researchers who are interested in the relationship between student selfefficacy and their MOOC behaviors agreed that self-efficacy is one important predictor of students' MOOC behaviors. For instance, self-efficacy influences student intention to use MOOC (GovindAarajan \& Krishnan, 2019; T Subramaniam, Suhaimi, Latif, Abu Kassim, \& Fadzil, 2019), retention in MOOC (Jung \& Lee, 2018; Kim, Song, \& Lee, 2021; Sujatha \& Kavitha, 2018) or their completion rates (Branson, 2017). Self-efficacy predicts students' perceived requirements of the subject knowledge or technical skills, which affects their satisfaction with the MOOC (Rabin et al., 2020). In addition, self-efficacy correlates with other 
Arab World English Journal (AWEJ) 2nd Special Issue on Covid 19 Challenges January 2022

Taiwanese engineering students' self-efficacy and academic performance

Phan \& Chen

constructs such as the use of self-regulated learning strategies and impacts on students' learning experience in the MOOC (Ghazali, Nordin, Abdullah, \& Ayub, 2020) or their performance (Lee et al., 2020). Regarding the antecedents of self-efficacy, learners' demographic characteristics such as age, gender, educational background, and enrolment status, can predict students' academic MOOC self-efficacy (Branson, 2017). In terms of changes in self-efficacy, Rodriguez and Armellini (2017) and Bárkányi (2021) compared student self-efficacy at the beginning and the end of a MOOC. Findings showed that self-efficacy increased significantly after completing the MOOC.

The findings of all studies in the review above confirm the important role of self-efficacy in a MOOC environment. An examination of the participants and study fields shows that most research resides in Western economies and not in Asian countries. No studies up to this point have explored the change in engineering student self-efficacy before and after they finish a MOOC or the relationship between engineering students' self-efficacy and academic performance in a MOOC learning environment. Owing to a dearth of research exploring selfefficacy in this environment, the present study was conducted.

\section{Methods}

\section{Participants}

A sample of 113 full-time undergraduates and 9 part-time graduate students participated in the present study. Their age ranged from 19 to 35 years. One hundred and four were male and 18 were female. Only seventeen students had had previous experience with MOOCs. Fifty-one students were at the beginner's level of English proficiency, followed by the intermediate (35 students), elementary (22 students), and lower intermediate (14 students) levels.

\section{Context}

The course "Technical Writing" is offered as a blended learning course at a university in Taiwan. One hundred and twenty-two students attended the regular class once a week with 2 hours per session. They were required to enroll in and take the pilot MOOC on English Technical Writing Skills, which was facilitated by the Advanced Power Energy Center, National Yi-Lan University, Taiwan. The regular course ran for 15 weeks and the pilot MOOC was used as a part of the syllabus, providing the students with MOOC platform-supported activities. A Microsoft Teams account was created and used as a class communication channel. The pilot MOOC contained four topics: Introduction to English Technical Writing Skills, Writing a Resume, Writing a Simple Technical Instruction, and Sketching out Your Business Model. The students were required to take the MOOC outside class hours. The completion of the pilot MOOC accounted for $20 \%$ of the final course rating.

\section{Instruments}

\section{The Questionnaire}

The study used a questionnaire to measure the self-efficacy of 122 engineering students before and after they took the blended MOOC. The questionnaire has two sections. Section 1 explores students' demographic information about age, gender, English Proficiency level, educational level, and the number of prior MOOCs. Section 2 is an 11-point Likert self-efficacy scale ranging from 0 (cannot do at all) to 10 (highly certain can do). The scale consists of 3 dimensions: self-efficacy in technology use (10 items), self-efficacy in time management (9 
Arab World English Journal (AWEJ) 2nd Special Issue on Covid 19 Challenges January 2022

items), and English self-efficacy (11 items). The Online Learning Self-Efficacy Scale (Zimmerman \& Kulikowich, 2016) was adapted in the present study. The questionnaire was written in Chinese and delivered online. Quantitative data were analyzed using SPSS 20.0 for Windows. The reliability with Cronbach's alpha value was identified as .956, .936, and .969 for the self-efficacy in technology use subscale, the self-efficacy in independent learning subscale, and the English self-efficacy subscale respectively. The value of KMO was .949 and Bartlett's test was highly significant $(\mathrm{p}<.001)$. The researchers conducted an exploratory factor analysis to examine the construct-related validity of the scale dimensions. Seven items were removed from the scale since they were cross-loaded and a difference being smaller than 0.3 was found between loadings. The analysis was repeated after the items were removed. The factor loading distributions ranged between .548 and .862 . Based on the loading distributions, twenty-three question items of the scale were arranged into three dimensions, namely English self-efficacy (7 items), self-efficacy in technology use (9 items), and self-efficacy in independent learning (7 items).

\section{Test Instruments}

In our study, student performance was calculated by course final grades which were derived from class discussion, class attendance, final test, and the MOOC scores.

\section{Procedures}

The questionnaire was sent to the students before they attended the course. The students were informed that their personal information would be treated complete and used for research purposes only. One hundred and twenty-two students filled out the online survey. Participating students were invited to answer the survey the second time before doing the final test of the course.

\section{Data analysis}

The Statistical Package for Social Sciences (SPSS) version 20.0 was used to analyze the data in this study. A Paired-samples t-test helped to measure differences in self-efficacy scores at the beginning and end of the course. Pearson correlation was conducted to examine if self-efficacy predicted students' course grades at the end of the course. Descriptive analysis, t-test, and ANOVA were used to measure the differences between the mean scores of self-efficacy and academic performance regarding different demographic variables.

\section{Results}

Self-efficacy before and after the blended MOOC

Table 1. Self-efficacy before and after the blended MOOC

\begin{tabular}{lrrrrr}
\hline Self-efficacy scores & Mean & N & Std. Deviation & Std. Error Mean & Sig. (2-tailed) \\
\hline Before & 6.109 & 122 & 1.760 & .159 & .000 \\
\hline After & 6.920 & 122 & .933 & .084 & .00 \\
\hline
\end{tabular}

The results in table 1 indicate that there is a significant difference in the self-efficacy levels after students finished the course ( $\mathrm{sig}=.000<0.05$ ). The students reported a higher sense of selfefficacy as the mean ratings for self-efficacy before and after the course were 6.109 and 6.920 respectively. 
Arab World English Journal (AWEJ) 2nd Special Issue on Covid 19 Challenges January 2022

Taiwanese engineering students' self-efficacy and academic performance

Relationship between self-efficacy beliefs and academic performance

Table 2. Descriptive Statistics

\begin{tabular}{llll}
\hline & Mean & Std. Deviation & N \\
\hline Score & 69.2541 & 11.53977 & 122 \\
\hline Self-efficacy & 6.9209 & .93344 & 122 \\
\hline
\end{tabular}

Table 3. Correlations between self-efficacy and academic performance

\begin{tabular}{|c|c|c|c|}
\hline & & Self-efficacy & score \\
\hline \multirow{3}{*}{ Self-efficacy } & Pearson Correlation & 1 & $.830^{* *}$ \\
\hline & Sig. (2-tailed) & & .000 \\
\hline & $\mathrm{N}$ & 122 & 122 \\
\hline \multirow{3}{*}{ Score } & Pearson Correlation & $.830^{* *}$ & 1 \\
\hline & Sig. (2-tailed) & .000 & \\
\hline & $\mathrm{N}$ & 122 & 122 \\
\hline
\end{tabular}

**. Correlation is significant at the 0.01 level (2-tailed).

There was a correlation between self-efficacy and academic performance $($ sig $=.000<0.05)$ and the correlation was quite strong ( $\mathrm{r}$-value $>0.7$ ). Self-efficacy significantly predicted academic performance. Students who displayed a stronger sense of self-efficacy achieved better scores.

\section{Self-efficacy and academic performance regarding different demographic variables}

Table 4: Results of Independent Samples Test of male and female students

\begin{tabular}{|c|c|c|c|c|c|c|}
\hline \multirow{2}{*}{ Variables } & \multicolumn{2}{|c|}{ Male $(N=104)$} & \multicolumn{2}{|c|}{ Female $(\mathrm{N}=18)$} & \multirow{2}{*}{$\begin{array}{c}\text { Levene's } \\
\text { test }\end{array}$} & \multirow{2}{*}{$\begin{array}{l}\text { Level of } \\
\text { significance }\end{array}$} \\
\hline & Mean & SD & Mean & $\mathrm{SD}$ & & \\
\hline Score & 68.990 & 11.424 & 70.777 & 12.417 & .547 & -.924 \\
\hline Self-efficacy & 6.888 & .920 & 7.108 & 1.011 & .567 & -.605 \\
\hline
\end{tabular}

The results show that male and female students did not differ significantly in their self-efficacy and academic score as Levene's test statistic is greater than 0.05 and the p-value is greater than 0.05 .

Table 5: Results of One-way ANOVA Test as related to age group

\begin{tabular}{|c|c|c|c|c|c|}
\hline & Age group & $\mathrm{N}$ & Mean & $\mathrm{Sig}_{\text {Levene }}$ & $\operatorname{Sig}_{\text {Welch }}$ \\
\hline \multirow{4}{*}{ Self-efficacy } & Under 20 & 26 & 6.866 & \multirow{4}{*}{.001} & \multirow{4}{*}{.000} \\
\hline & $20-25$ & 87 & 7.017 & & \\
\hline & Above 30 & 9 & 6.144 & & \\
\hline & Total & 122 & 6.920 & & \\
\hline \multirow{4}{*}{ Score } & Under 20 & 26 & 67.846 & \multirow{4}{*}{.004} & \multirow{4}{*}{.000} \\
\hline & $20-25$ & 87 & 70.816 & & \\
\hline & Above 30 & 9 & 58.222 & & \\
\hline & Total & 122 & 69.254 & & \\
\hline
\end{tabular}

The results show that participants differed significantly in their self-efficacy and academic performance as related to age group. The students aged above 30 were less self-efficacious and their academic performance was lower than students belonging to other age groups.

Table 6: Results of One-way ANOVA Test with respect to educational level 
Arab World English Journal (AWEJ) 2nd Special Issue on Covid 19 Challenges January 2022

Taiwanese engineering students' self-efficacy and academic performance

Phan \& Chen

\begin{tabular}{|c|c|c|c|c|c|}
\hline & Education level & $\mathrm{N}$ & Mean & Sig Levene & $\operatorname{Sig}_{\text {Welch }}$ \\
\hline \multirow{5}{*}{ Self-efficacy } & Sophomore & 82 & 6.872 & \multirow{5}{*}{.000} & \multirow{5}{*}{.000} \\
\hline & Junior & 20 & 7.121 & & \\
\hline & Senior & 11 & 7.553 & & \\
\hline & Master's Degree & 9 & 6.144 & & \\
\hline & Total & 122 & 6.920 & & \\
\hline \multirow{5}{*}{ Score } & Sophomore & 82 & 68.817 & \multirow{5}{*}{.000} & \multirow{5}{*}{.000} \\
\hline & Junior & 20 & 70.850 & & \\
\hline & Senior & 11 & 78.636 & & \\
\hline & Master's Degree & 9 & 58.222 & & \\
\hline & Total & 122 & 69.254 & & \\
\hline
\end{tabular}

The results show that participants differed significantly in their self-efficacy and academic performance with respect to educational level. Graduate students were less self-efficacious than undergraduate students and their academic performance was lower than undergraduate students.

Table 7: Results of One-way ANOVA Test with respect to English proficiency level

$\begin{array}{lllll}\text { English proficiency level } & \mathrm{N} & \text { Mean } & \mathrm{Sig}_{\text {Levene }} & \\ \end{array}$

\begin{tabular}{|c|c|c|c|c|c|}
\hline \multirow{5}{*}{ Self-efficacy } & Beginner & 51 & 6.653 & \multirow{5}{*}{.346} & \multirow{5}{*}{.007} \\
\hline & Elementary & 22 & 7.237 & & \\
\hline & Low Intermediate & 14 & 6.633 & & \\
\hline & Intermediate & 35 & 7.227 & & \\
\hline & Total & 122 & 6.920 & & \\
\hline \multirow{5}{*}{ Score } & Beginner & 51 & 65.607 & \multirow{5}{*}{.602} & \multirow{5}{*}{.011} \\
\hline & Elementary & 22 & 72.681 & & \\
\hline & Low Intermediate & 14 & 67.857 & & \\
\hline & Intermediate & 35 & 72.971 & & \\
\hline & Total & 122 & 69.254 & & \\
\hline
\end{tabular}

The results show that participants differed significantly in their self-efficacy and academic performance with respect to English proficiency level. Students at elementary and intermediate levels were more self-efficacious and their academic performance was better than students at beginner and lower intermediate levels.

Table 8: Results of One-way ANOVA Test with respect to the number of prior MOOCs

\begin{tabular}{|c|c|c|c|c|c|}
\hline & Number of prior MOOCs & $\mathrm{N}$ & Mean & Sig $_{\text {Levene }}$ & $\operatorname{Sig}_{F}$ \\
\hline \multirow{4}{*}{ Self-efficacy } & None & 105 & 6.846 & \multirow{4}{*}{.094} & \multirow{4}{*}{.082} \\
\hline & One & 12 & 7.333 & & \\
\hline & More than one & 5 & 7.504 & & \\
\hline & Total & 122 & 6.920 & & \\
\hline \multirow{4}{*}{ Score } & None & 105 & 68.600 & \multirow{4}{*}{.220} & \multirow{4}{*}{.240} \\
\hline & One & 12 & 72.083 & & \\
\hline & More than one & 5 & 76.200 & & \\
\hline & Total & 122 & 69.254 & & \\
\hline
\end{tabular}

The results show that students did not differ significantly in their self-efficacy and academic score with respect to the number of completed MOOCs as the value of Levene's test statistic is greater than 0.05 and the value of the ANOVA test is greater than 0.05 . 
Arab World English Journal (AWEJ) 2nd Special Issue on Covid 19 Challenges January 2022

\section{Discussion and Conclusion}

Higher sense of self-efficacy levels as a result of attending the blended MOOC

In our study, students became more self-efficacious after they attended the blended MOOC. This finding confirms the usefulness of the course in improving students' self-efficacy. Some researchers, e.g. Rodriguez and Armellini (2017) and Bárkányi (2021), have also discussed the positive change of self-efficacy resulting from their participation in a MOOC. However, it is still unclear in our study and other previous studies how self-efficacy was changed throughout the course. Phan and Locke (2015) and Phan (2016) mentioned the role of context in mediating individual self-efficacy. Wyatt (2014) suggested the use of longitudinal, mixed-methods designs in understanding changes in self-efficacy. Owing to the dearth of self-efficacy research in a MOOC environment and the dominance of quantitative self-efficacy research (Wyatt, 2015), future studies may want to take the suggestion of these researchers into account.

\section{Relationship between self-efficacy and academic performance}

In this study, self-efficacy significantly predicted academic performance. Students who reported higher self-efficacy levels gained better scores. This finding corroborates most of the findings in previously cited studies across domains and confirms the positive relationship between selfefficacy and students' academic achievement (Branson, 2017; Lee et al., 2020). In a MOOC learning environment where the dropout rate remains high and the poor academic performance is regarded as one of the crucial reasons (Daniel, 2012; Sandeen, 2013), the important role that selfefficacy plays on academic achievement suggests that the improvement of students' self-efficacy will likely encourage students' perseverance in their registered MOOCs.

\section{Self-efficacy and academic performance with respect to demographic variables}

In our study, participants differed significantly in their self-efficacy and academic performance in relation to age group, English proficiency level, and educational level. Recognizing these factors can help teachers and educators to use effective interventions in the classroom to promote both self-efficacy and learning achievement in a MOOC environment. One of the interventions can be the administration of placement tests (Uchidiuno, 2016) before students can register for a specific MOOC. The placement tests aim at helping the learners determine whether the course is suitable to their current English and subject knowledge levels. In addition, clear course introduction and virtual course orientations (Cho \& Byun, 2017) may help students to form appropriate learning objectives through their clear understanding of course requirements. Providing "personalized, tailor-made assistance tools" (Rabin et al., 2020) is another kind of support that possibly makes learners at different age groups improve their self-efficacy and learning achievement. Future mixed-methods studies should dig out the relationship between the three demographic variables, self-efficacy and learning achievement. It's also important to figure out what features of MOOCs can affect self-efficacy.

The present study has several limitations. The main limitation is a lack of a control group to test the impact of the blended MOOC on the constructs of self-efficacy, and the corresponding impact of several demographic factors on self-efficacy and academic performance. The sample size is another limitation. To increase the validity of findings, a greater number of participants in further research are desirable. 
Arab World English Journal (AWEJ) 2nd Special Issue on Covid 19 Challenges January 2022

About the Authors:

Nga Thi Tuyet Phan got her M.A. degree in TESOL Studies from the University of Queensland, Australia in 2005 and a Ph.D. degree in Education from Waikato University, New Zealand in 2015. Her research interests include self-efficacy, motivation, and course effectiveness. ORCiD: https://orcid.org/0000-0003-1289-3718

Cheng-Hu Chen received his M.S. and Ph.D. degrees in Mechanical Engineering and Electrical Engineering from the National Cheng Kung University, Tainan, Taiwan in 1999 and 2006, respectively. He is currently an Associate Professor of the Department of Mechanical and Electro-Mechanical Engineering at National Yi-lan University, Taiwan.

\section{References}

Anderson, T. (2013). Promise and/or peril: MOOCs and open and distance education. Commonwealth of learning, 3, 1-9.

Ayoub, A., Amin, R., \& Wani, Z. A. (2020). Contribution of developed countries towards MOOCs: an exploration and assessment from a representative platform Coursera. Asian Association of Open Universities Journal.

Bandura, A. (1986). Social foundations of thought and action: A social cognitive theory. NJ: Prentice-Hall: Englewood Cliffs.

Bárkányi, Z. (2021). Motivation, self-efficacy beliefs, and speaking anxiety in language MOOCs. ReCALL, 33(2), 143-160. doi:10.1017/s0958344021000033

Branson, K. J. (2017). Academic Self-Efficacy and Massive Open Online Course (MOOC) Completion Rates: Do Academic Self-Efficacy and Adult Learner Characteristics Influence MOOC Outcomes?

Chang, Y.-L., Tseng, C.-M., \& Kang, S.-C. (2015). The Development and Validation of On-Line Self-Efficacy Scale in Learning MOOCs: An Example from the Engineering Graphics Course.

Chung, L.-Y. (2015). Exploring the effectiveness of self-regulated learning in massive open online courses on non-native English speakers. International Journal of Distance Education Technologies (IJDET), 13(3), 61-73.

Daniel, J. (2012). Making sense of MOOCs: Musings in a maze of myth, paradox and possibility. Journal of Interactive Media in Education, 2012(3).

Ghazali, N., Nordin, M. S., Abdullah, A., \& Ayub, A. F. M. (2020). The relationship between students' MOOC-efficacy and meaningful learning. Asian Journal of University Education, 16(3), 89-101.

GovindAarajan, P. B., \& Krishnan, A. R. (2019). A study on influence of web quality and self efficacy on massive open online courses (MOOCs) technology adoption by extending the Utaut model with reference to student MOOC users. Shanlax International Journal of Management, 7(2), 47-53.

Greene, J. A., Oswald, C. A., \& Pomerantz, J. (2015). Predictors of retention and achievement in a massive open online course. American Educational Research Journal, 52(5), 925-955.

Hamber, B., Jaffrey, A., \& Murphy, B. (2015). MOOCs and open learning at ulster university: research, consultation and recommendations on an institutional approach. available at: https://pure.ulster.ac.uk/ws/files/11532536/report-MOOC_Ulster_2015.pdf. 
Arab World English Journal (AWEJ) 2nd Special Issue on Covid 19 Challenges January 2022

Hodges, C. (2016). The development of learner self-efficacy in MOOCs. In Proceedings of Global Learn 2016 (pp. 517-522). Association for the Advancement of Computing in Education (AACE).

Jung, Y., \& Lee, J. (2018). Learning engagement and persistence in massive open online courses (MOOCS). Computers \& Education, 122, 9-22.

Kao, C.-P., Tsai, C.-C., \& Shih, M. (2014). Development of a survey to measure self-efficacy and attitudes toward web-based professional development among elementary school teachers. Journal of Educational Technology \& Society, 17(4), 302-315.

Kim, H.-E., Song, H.-D., \& Lee, Y.-c. (2021). The Effect of Academic Self-Efficacy, Perceived Usefulness, Perceived Ease of Use, and Acceptance Attitude on Learning Persistence through Student Engagement in MOOC. In T. Bastiaens (Ed.), Proceedings of EdMedia + Innovate Learning (pp. 892-897). United States: Association for the Advancement of Computing in Education (AACE). Retrieved November 26, 2021 from https://www.learntechlib.org/primary/p/219755/.

Lee, D., Watson, S. L., \& Watson, W. R. (2020). The relationships between self-efficacy, task value, and self-regulated learning strategies in massive open online courses. International Review of Research in Open and Distributed Learning, 21(1), 23-39.

Ma, L., \& Lee, C. S. (2018). Investigating the adoption of MOOCs: A technology-userenvironment perspective. Journal of Computer Assisted Learning, 35(5). doi:10.1111/jcal.12314

Pajares, F., \& Valiante, G. (2002). Students' self-efficacy in their self-regulated learning strategies: A developmental perspective. Psychologia, 45(4), 211-221.

Phan, N. T. T. (2016). The impact of context on Vietnamese EFL teachers' self-efficacy. Waikato Journal of Education, 21(1), 65-76.

Phan, N. T. T., \& Locke, T. (2015). Sources of self-efficacy of Vietnamese EFL teachers: A qualitative study. Teaching and Teacher Education, 52, 73-82. doi:http://dx.doi.org/10.1016/j.tate.2015.09.006

Pouezevara, S. R., \& Horn, L. (2016). MOOCs and online education: exploring the potential for international educational development: RTI Press/RTI International.

Rabin, E., Henderikx, M., Kalman, Y., M., \& Kalz, M. (2020). What are the barriers to learners' satisfaction in MOOCs and what predicts them? The role of age, intention, selfregulation, self-efficacy and motivation. Australasian Journal of Educational Technology, 36(3), 119-131. doi:10.14742/ajet.5919

Rodriguez, B. C. P., \& Armellini, A. (2017). Developing self-efficacy through a massive open online course on study skills. Open Praxis, 9(3), 335-343.

Sandeen, C. (2013). Integrating MOOCs into traditional higher education: The emerging "MOOC 3.0" era. Change: The magazine of higher learning, 45(6), 34-39.

Singh, V., \& Thurman, A. (2019). How many ways can we define online learning? A systematic literature review of definitions of online learning (1988-2018). American Journal of Distance Education, 33(4), 289-306.

Sujatha, R., \& Kavitha, D. (2018). Learner retention in MOOC environment: Analyzing the role of motivation, self-efficacy and perceived effectiveness. International Journal of Education and Development Using ICT, 14(2).

T Subramaniam, T., Suhaimi, N. A. D., Latif, L. A., Abu Kassim, Z., \& Fadzil, M. (2019). MOOCs readiness: The scenario in Malaysia. International Review of Research in Open and Distributed Learning, 20(3). 
Arab World English Journal (AWEJ) 2nd Special Issue on Covid 19 Challenges January 2022

Taipjutorus, W., Hansen, S., \& Brown, M. (2012). Linking between Learner Control and SelfEfficacy of Online Learners in a New Zealand Postgraduate Online Programme. Australian Association for Research in Education (NJ1).

Willis, J. E. (2013). MOOCs and Foucault's heterotopia: On community and self-efficacy. Retrieved from http://linc.mit.edu/linc2013/ proceedings/Session3/Session3Willis.pdf

Wyatt, M. (2014). Towards a re-conceptualization of teachers' self-efficacy beliefs: Tackling enduring problems with the quantitative research and moving on. International Journal of Research \& Method in Education, 37(2), 166-189.

Wyatt, M. (2015). Using qualitative research methods to assess the degree of fit between teachers' reported self-efficacy beliefs and their practical knowledge during teacher education. Australian Journal of Teacher Education, 40(1), 117-145. doi:10.14221/ajte.2015v40n1.7

Zimmerman, W. A., \& Kulikowich, J. M. (2016). Online learning self-efficacy in students with and without online learning experience. American Journal of Distance Education, 30(3), 180-191. 